\title{
THE GENUS PHRYGANEA (TRICHOPTERA) IN THE FLORISSANT SHALES.
}

\author{
By T. D. A. Cockerell. \\ The University of Colorado.
}

If it receives anything like the treatment it deserves, Ulmer's magnificent work, Die Trichoptera des Baltischen Bernsteins, will create much new interest, not only in the Trichoptera of amber, but in the general history and classification of the group. Among other things, it shows that as far back as the oligocene in Europe the genus Phryganea was very well represented, no less than seven species having been discovered in amber. When we consider that only 20 or 21 recent species are known in the world, it appears probable that in mid-tertiary times it was considerably richer in forms than at present; but the modern Neuronia, with quite numerous species, may be taken to represent an offshoot from the Phryganea of the tertiaries, some of the fossil species possessing more or less evident Neuronia-like characters.

In the Miocene shales of Florissant Colorado, Phryganea is represented, so far as at present known, by two species. One of these was long ago described by Scudder; the other is new. In addition, Scudder described a Neuronia evanescens, but its reference to Neuronia is doubtful. No definite idea of its venation can be gained from Scudder's figure, but his description is more explicit. Vein $\mathbf{R}_{2}$ leaves the discoidal cell "close to the base," a condition approached by the amber species Phryganea longirostris Hagen. On the other hand the discoidal cell is comparatively short, as is usual in Neuronia, while the $\mathbf{R}-\mathbf{M}$ cross vein is "widely separated" from the end of the discoidal cell, that is, considerably beyond it; an approach to the latter condition is shown by the amber species $P$. egregia Ulmer and $P$. picea Pictet. An exact drawing of the venation of $N$. evanescens, based on Scudder's type, is much to be desired.

\section{Phryganea labefacta Scudder.}

I have before me a very well preserved anterior wing, collected by my wife at Station 17 . It is $19 \frac{1}{4} \mathrm{~mm}$. long, and a little over $7 \frac{1}{2}$ broad; the discoidal cell is $6 \frac{1}{3} \mathrm{~mm}$. long; end of discoidal cell 
to apex of wing $7 \mathrm{~mm}$.; length of cellula thyridii $7 \mathrm{~mm}$. In some ways, this species is suggestive of Neuronia. Scudder's figure shows a distinct mottling, suggestive of $N$. pardalis Walker, but the apex of the wing is much blunter than in pardalis. In shape, the wing is more like that of $N$. ruficrus, but the apical part of the costa is not so rounded as in that insect, and the anal angle is rather more distinct. The wing-form of $P$. labefacta is not unlike that of the amber $P$. longirostris Hagen, but our insect has the costa much straighter, the anal angle more distinct, and the wing hardly so broad in proportion to its length. The comparatively distinct anal angle is as in the amber $P$. singularis Ulmer.

\section{Phryganea miocenica sp. nov.}

A very fine species, collected by one of the University of Colorado expeditions, but the collector and station are not recorded. It is represented by an upper wing, very well preserved except for the loss of a considerable part of the region of the anal angle. It appears to represent a female, and is a quite typical Phryganea, with relatively long wings.

Upper wing about $24 \mathrm{~mm}$. long, 9 wide, as preserved red-brown, the costal region broadly darkened, the anal region dusky, the veins dark on a lighter ground. Owing to the dark costal cell, the oblique cross-vein between the costa and subcosta cannot be clearly demonstrated, but a kink in the subcosta indicates its point of origin. The discoidal cell is about $7 \frac{1}{8} \mathrm{~mm}$. long; cellula thyridii $9 \mathrm{~mm}$.; apex of wing to base of discoidal cell slightly over $16 \mathrm{~mm}$.

Compared with the female of the amber P.latissima Ulmer, there is close agreement in venation, though our insect is much longerwinged than latissima, yet not so long (narrow) winged as $\boldsymbol{P}$. dubia. Compared with $\boldsymbol{P}$. latissima, the second anal cell of $\boldsymbol{P}$. miocenica is longer and narrower, its lower side more convex; the cellula thyridii is longer and narrower; the apical angle of the discoidal cell is much more acute. The lower branch of the media forks is in o latissima; owing to the loss of part of the wing, only the extreme base of the fork is visible.

This is the largest of the Florissant Trichoptera, and is considerably larger than any of the amber species of Phryganea. 

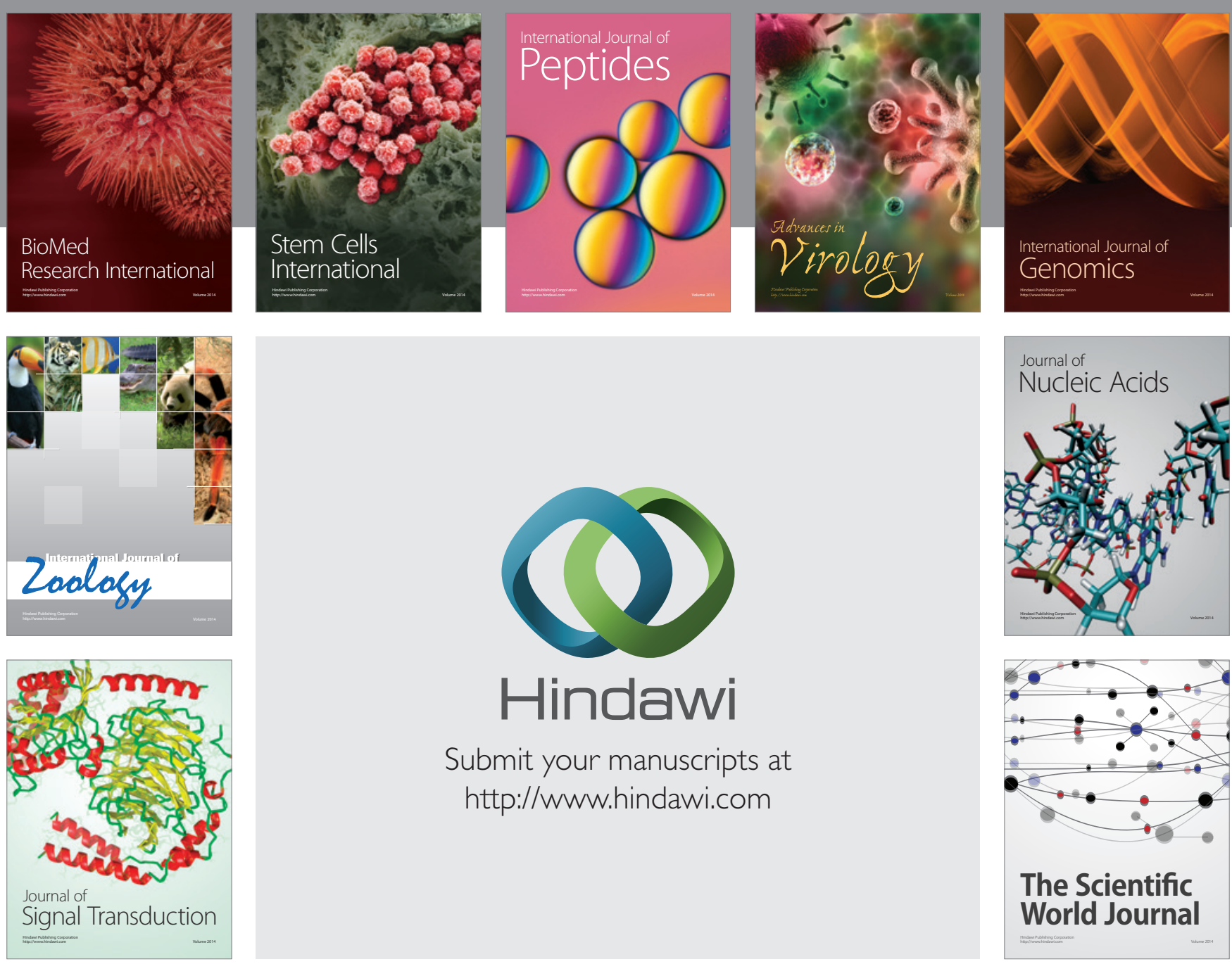

Submit your manuscripts at

http://www.hindawi.com
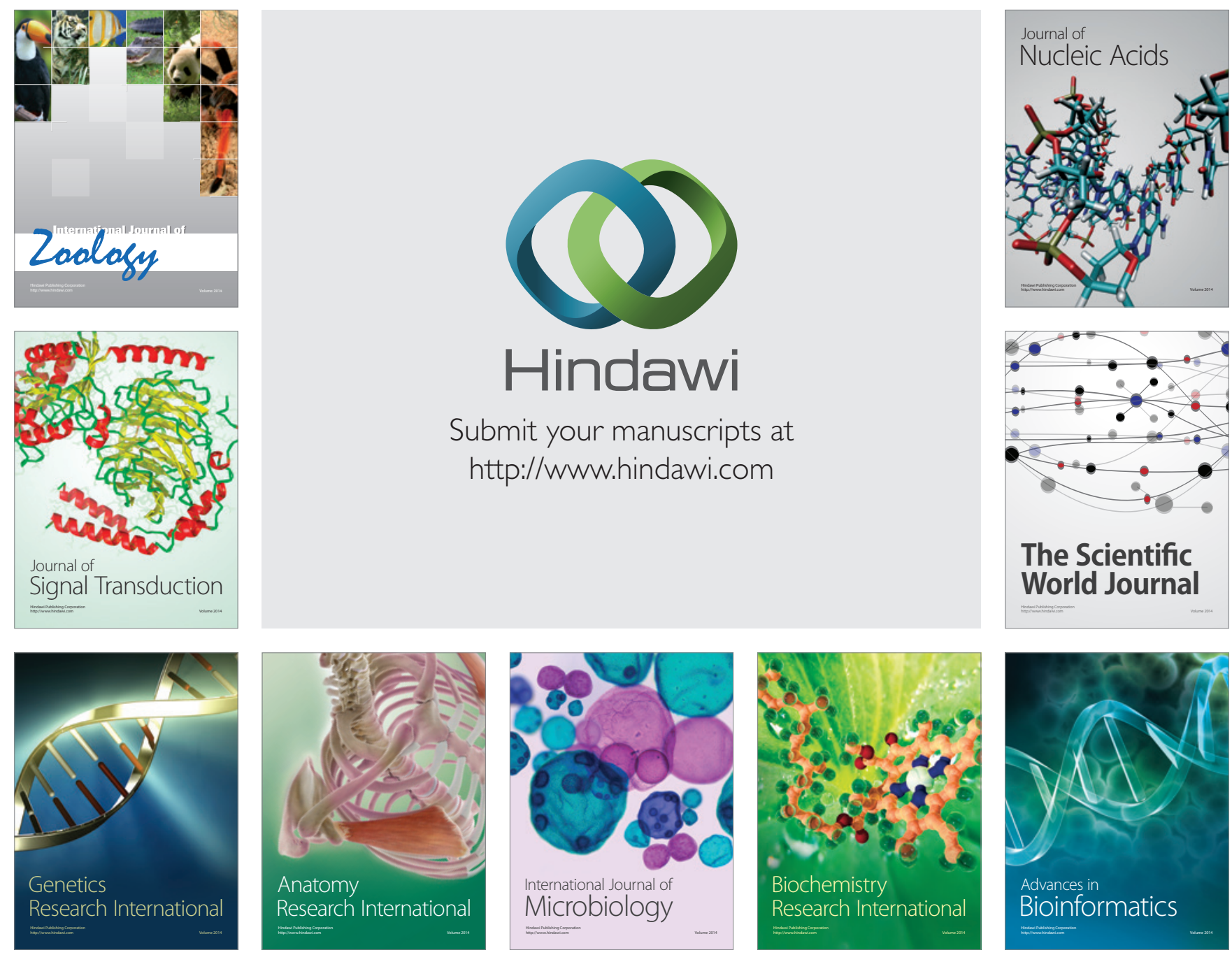

The Scientific World Journal
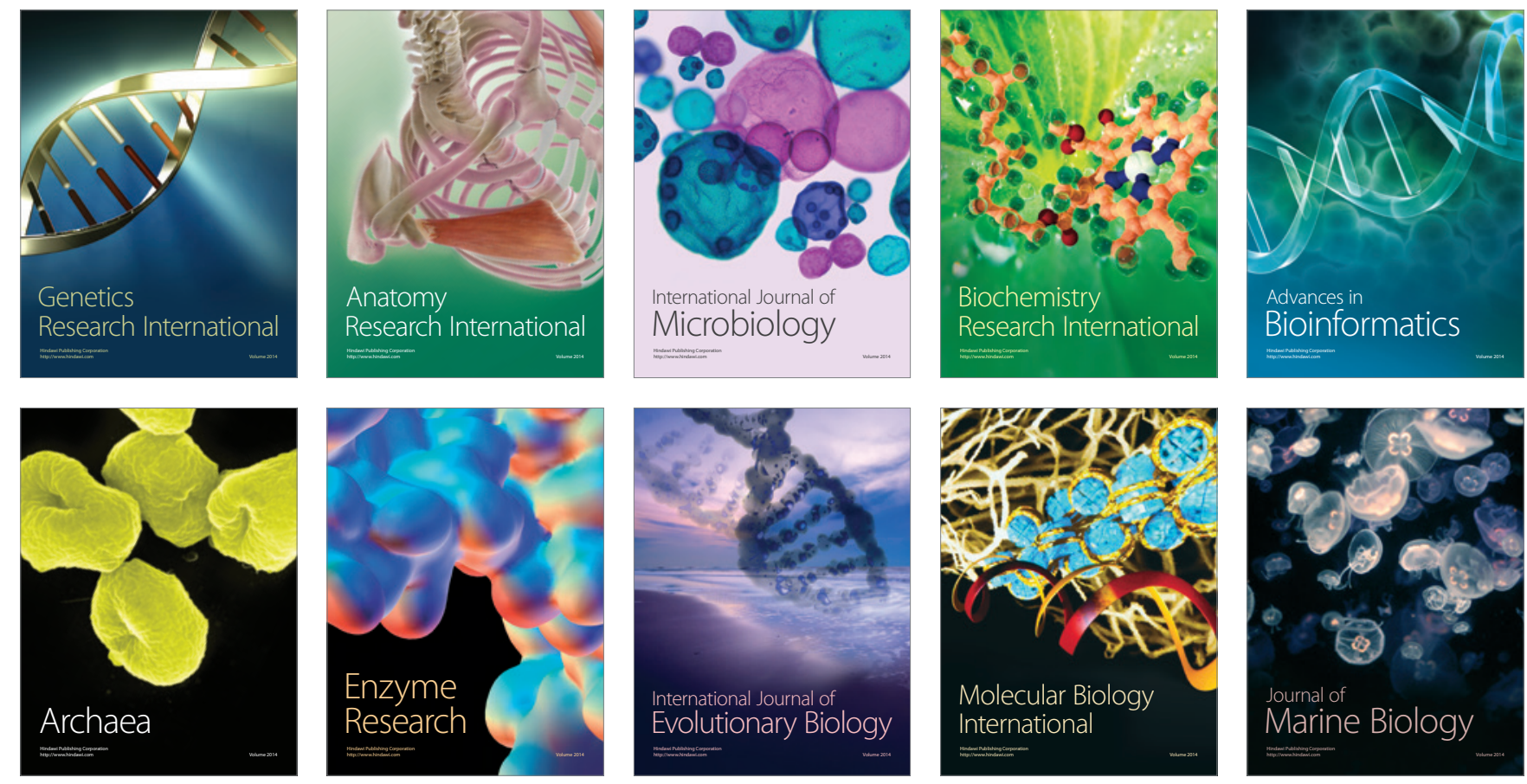